Foss. Rec., 21, 93-107, 2018

https://doi.org/10.5194/fr-21-93-2018

(C) Author(s) 2018. This work is distributed under

the Creative Commons Attribution 4.0 License.

\title{
A new pachyrhizodontid fish (Actinopterygii, Teleostei) from the Muhi Quarry (Albian-Cenomanian), Hidalgo, Mexico
}

\author{
Gloria Arratia $^{1}$, Katia A. González-Rodríguez ${ }^{2}$, and Citlalli Hernández-Guerrero ${ }^{2,3}$ \\ ${ }^{1}$ Biodiversity Institute and Department of Ecology and Evolutionary Biology, The University of Kansas, Dyche Hall, \\ Lawrence, Kansas 66045-7561, USA \\ ${ }^{2}$ Instituto de Ciencias Básicas e Ingeniería, Museo de Paleontología, Centro de Investigaciones Biológicas, Universidad \\ Autónoma del Estado de Hidalgo, Mineral de la Reforma, Hidalgo, Mexico \\ ${ }^{3}$ Doctorado en Ciencias en Biodiversidad y Conservación, Universidad Autónoma del Estado de Hidalgo, Mineral de la \\ Reforma, Hidalgo, Mexico
}

Correspondence: Katia A. González-Rodríguez (katiag@uaeh.edu.mx)

Received: 20 October 2017 - Revised: 15 February 2018 - Accepted: 16 February 2018 - Published: 28 March 2018

\begin{abstract}
A new genus and species - Motlayoichthys sergioi (ZooBank registration: urn:1sid:zoobank.org:pub:2C503741-2362-4234-8CE0-

BB7D8BE5A236, urn:lsid:zoobank.org:act:EF5040FDF306-4C0F-B9DA-2CC696CA349D) - from the Cretaceous (Albian-Cenomanian) of the Muhi Quarry, Hidalgo, central Mexico is assigned to the family Pachyrhizodontidae based on the presence of the inner premaxillary tooth and a few other cranial characters. Its unique suite of characters, that includes several autapomorphies supports its assignment as a new genus and species, such as the presence of a triangular head with three sides of similar lengths and with its deepest part at the level of the supraoccipital region; the lower jaw projecting anterior to the premaxilla; the ornamentation of cranial bones - especially those of the cheek region consisting of fine longitudinal crests densely covering the bony surfaces; one or a few deep grooves on the mandibular teeth, which in addition bear acrodin tips ornamented with fine parallel striae; and the position of the dorsal fin, near the posterior margin of the cranium. Motlayoichthys n. gen., together with Michin, Pachyrhizodus, Rhacolepis, and Notelops, is part of the early radiation of pachyrhizodontoids during Albian times.
\end{abstract}

\section{Introduction}

Pachyrhizodontidae is a family of now extinct fishes found throughout the Tethys Ocean during the Cretaceous. The family belongs to the order Crossognathiformes (Taverne, 1989, sensu Arratia, 2008a; Arratia and Tischlinger, 2010) and the suborder Pachyrhizodontoidei (sensu Forey, 1977). Ten genera are currently referred to Pachyrhizodontidae: Rhacolepis Agassiz, 1841; Pachyrhizodus Dixon, 1850 ( = Thrissopater Günther, 1872); Elopopsis Heckel, 1856; Greenwoodella Taverne, 1973; Platinx Taverne, 1980; Goulmimichthys Cavin, 1995; Tingitanichthys Taverne, 1996; Michin Alvarado-Ortega et al., 2008; Nardopiscis Taverne, 2008; and Aquilopiscis Cumbaa and Murray, 2008. Rhacolepis and Notelops Woodward, 1901 are interpreted here as crossognathiforms following Arratia's (2008a) and Arratia and Tischlinger's (2010) phylogenetic hypotheses. In contrast, both genera were interpreted as elopomorphs by Maisey (1991a, b). Notelops was included in its own family, Notelopidae, by Forey (1977), an arrangement followed by Nelson et al. (2016). However, it appears in an unresolved position within a non-monophyletic order Pachyrhizodontoidei in the phylogenetic hypotheses of Cumbaa and Murray (2008: fig. 12) and Arratia and Tischlinger (2010: fig. 12).

New records of the family have been found in some Cretaceous localities of Mexico, including Michin csernai (Alvarado-Ortega et al., 2008), Rhacolepis sp. from the Albian Tlayúa Quarry of Puebla (Espinosa-Arrubarrena and Alvarado-Ortega, 2010), Goulmimichthys roberti (Blanco and Cavin, 2003; González-Rodríguez et al., 2013a), 


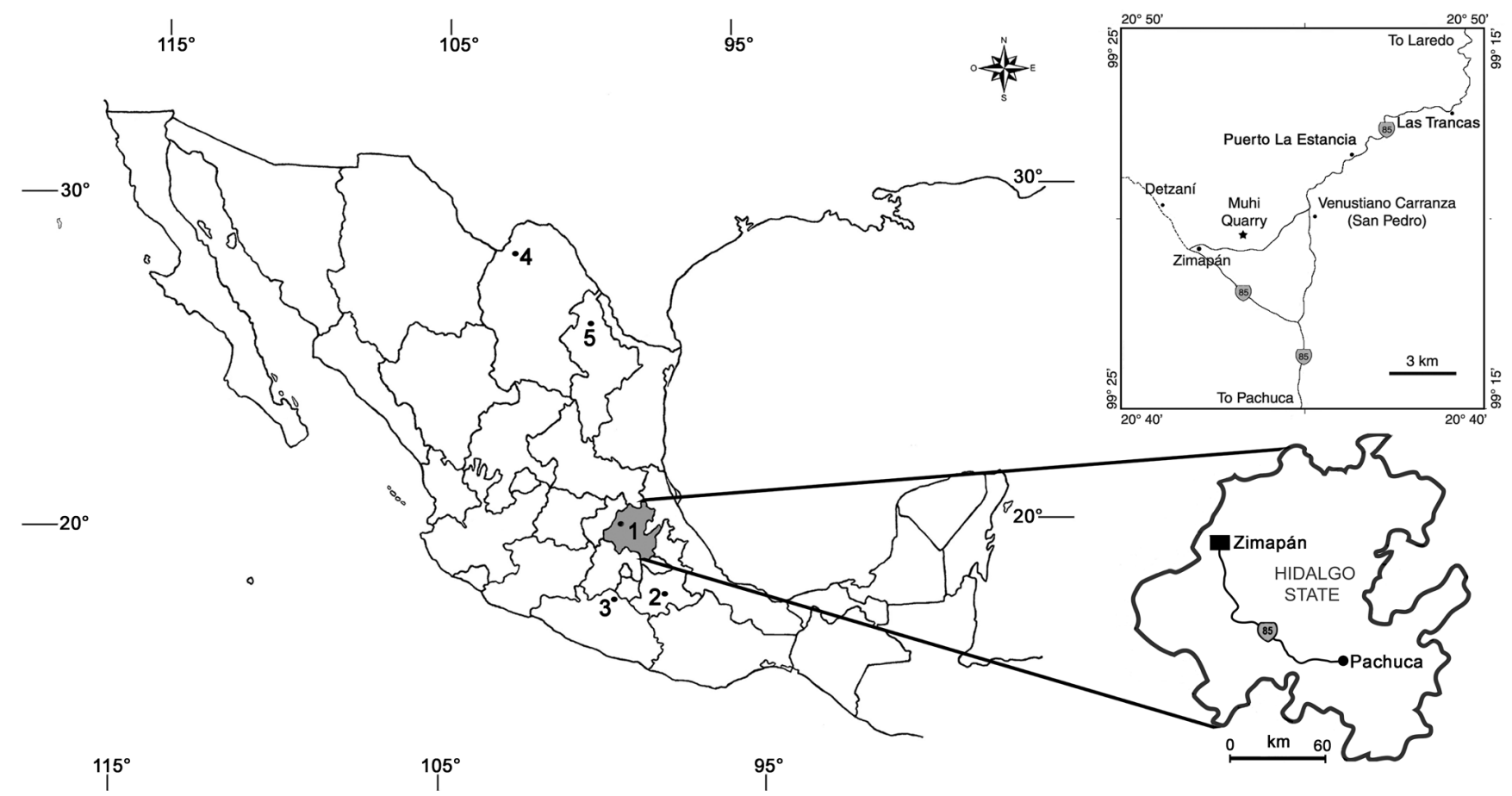

Figure 1. Map of Mexico showing the location of the Muhi Quarry and the sites where pachyrhizodontids have been found. (1) Muhi Quarry (Albian-Cenomanian), Zimapán, Hidalgo state, central Mexico; (2) Tlayúa Quarry (Albian), located in the Morelos District of Puebla, central Mexico; (3) Mexcala Formation quarries (Turonian-Maastrichtian), northern portion of the state of Guerrero; (4) La Mula Quarry (Turonian), Múzquiz District, Coahuila, northern Mexico; (5) Vallecillo Quarry (Lower Turonian), Nuevo León state, northern Mexico. Modified from González-Rodríguez et al. (2013a).

Pachyrhizodus caninus (Giersch et al., 2010b; GonzálezRodríguez et al., 2013a), and Tingitanichthys sp. from the lower Turonian locality Vallecillo in Nuevo León State (Giersch et al., 2010a; González-Rodríguez et al., 2016), as well as the records of Goulmimichthys sp. from La Mula Quarry (Turonian), Múzquiz, Coahuila, northern Mexico; Eagle Ford Formation (Blanco-Piñón and Alvarado-Ortega, 2005), Pachyrhizodus sp. from Turonian-Maastrichtian sediments of Guerrero state (Alvarado-Ortega et al., 2006; GonzálezRodríguez et al., 2016), and the pachyrhizodontid of Muhi Quarry here described.

The Muhi Quarry (Fig. 1) is a fossil Lagerstätte that was discovered almost 20 years ago in state of Hidalgo, central México (Bravo-Cuevas et al., 2012). More than two thousand fossils have been recovered from the site, which include ammonites, crustaceans, crinoids, numerous fishes and two reptiles (González-Rodríguez et al., 2013a, 2016). The material is deposited in the Museo de Paleontología of the Universidad Autónoma del Estado de Hidalgo (UAHMP), and many groups are under study.

The quarry belongs to the La Negra Facies of the El Doctor Formation of Albian-Cenomanian age (Fig. 2). The original section measured consists of a $7.2 \mathrm{~m}$ sequence of biomicrite and micrite limestones, with intercalated bedded and nodular cherts, and scarce laminae of unconsolidated siliciclastic clay and calcium carbonate (Bravo-Cuevas et al., 2009, 2012). The paleoenvironment corresponds to an outer sea shelf, which occasionally received both open-ocean and near-shore waters possibly due to storms (GonzálezRodríguez and Bravo-Cuevas, 2005; Bravo-Cuevas et al., $2009,2012)$. This mixture of waters promoted the deposition of a diverse pelagic and neritic fauna, such as the pachyrhizodontid fish. Fishes found in the locality include chondrichthyans (sharks and rays), neopterygians incertae sedis (Pycnodontiformes; previously cited as halecostomes in González-Rodríguez et al., 2016), actinistians (Schultze and González-Rodríguez, 2016), and numerous and diverse teleosts (González-Rodríguez et al., 2016) and the following teleosts have been recovered: Crossognathiformes, Ichthyodectiformes, Elopiformes, Tselfatiformes, Clupeiformes, Gonorynchiformes (González-Rodríguez et al., 2013a), Aulopiformes (Fielitz and González-Rodríguez, 2008, 2010), and Acanthomorpha (González-Rodríguez and Fielitz, 2008; González-Rodríguez et al., 2013b).

The goals of this paper are to describe and provide a taxonomic name to a new pachyrhizodontid from the Muhi Quarry (that represents the first specimen of the Muhi Quarry deposited in the Paleontological Collection of the University of the State of Hidalgo, Mexico) and to characterize it 
(a)

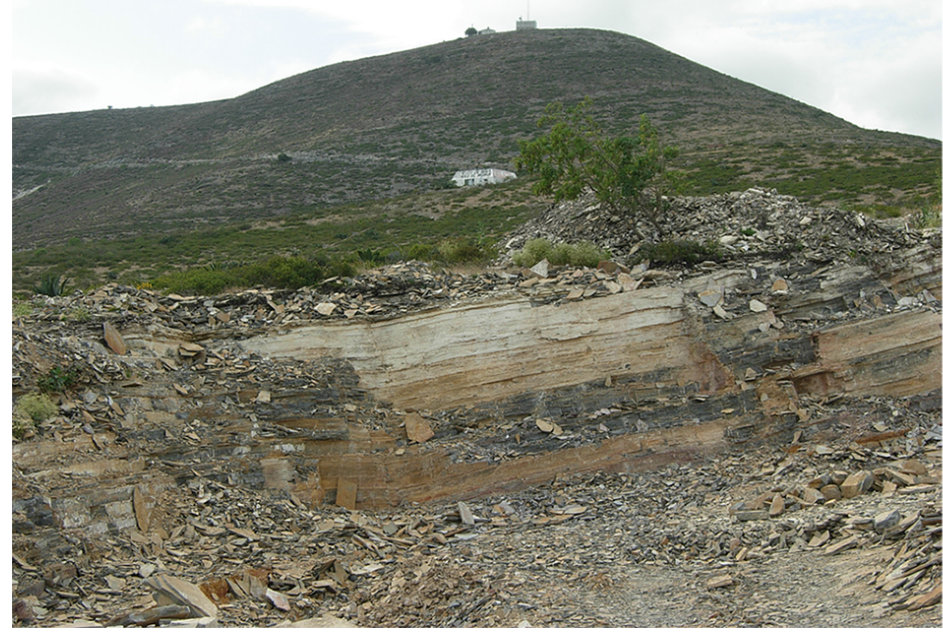

(b)

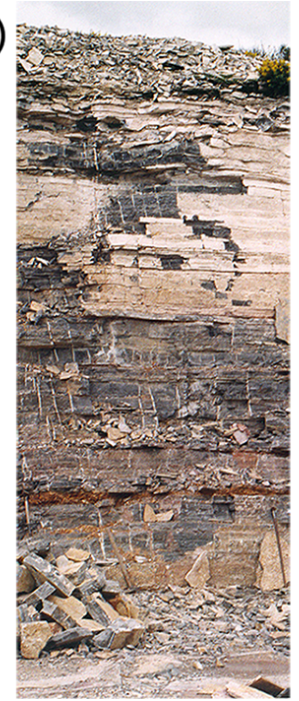

(c)

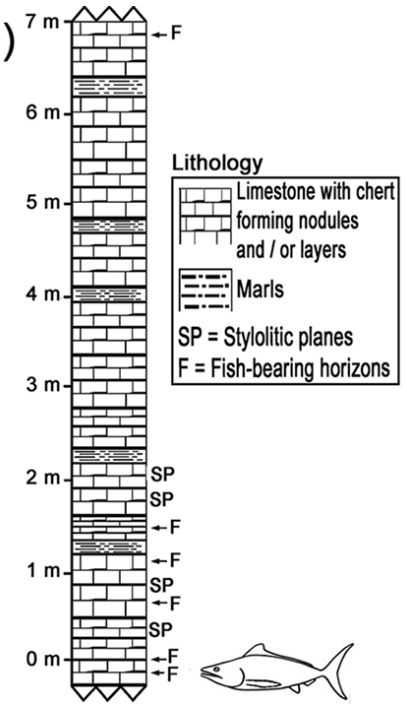

Figure 2. (a) Panoramic of the Muhi Quarry, Hidalgo, Mexico; (b) close-up view of a sequence of the Muhi Quarry; (c) stratigraphic column of the Muhi Quarry indicating the site where Motlayoichthys sergioi n. gen. et n. sp. was collected. Modified from Bravo-Cuevas et al. (2009) and Hegna et al. (2014).

within other Cretaceous Mexican pachyrhizodontids, as well as worldwide forms.

\section{Material and methods}

\subsection{Institutional abbreviations}

The studied material is housed in the following institutions: UAHMP, Museo de Paleontología, Universidad Autónoma del Estado de Hidalgo, Mexico; IGM, "Ma. Carmen Perrilliat" Museum, Instituto de Geología, Universidad Nacional Autónoma de México; KUVP, Division of Vertebrate Paleontology, Natural History, Museum, University of Kansas, Lawrence, Kansas, United States.

\subsection{Material studied}

The following specimens were used in comparative studies: Michin csernai from the Albian Tlayúa Quarry of Mexico (IGM-9028 to IGM-9034); Pachyrhizodus sp. (KUVP297, KUVP-271, KUVP-49416, KUVP-69014, KUVP276, KUVP-85127, KUVP-86210, KUVP-87698, KUVP98, KUVP-496, KUVP-391, KUVP-68976, KUVP-68986, KUVP-68987, KUVP-68994, KUVP-68997, KUVP-69009, KUVP-69400, KUVP-69407, KUVP-392, KUVP-69408, KUVP-69702, KUVP-13924, KUVP-16237, KUVP-59032) from the Niobrara Chalk and Pachyrhizodus minimus (KUVP-300 and KUVP-36032).

\subsection{Preparation and observation methods}

The right side of the head was prepared first with needles under a stereomicroscope and with acetic acid at $10 \%$ to elimi- nate part of the matrix in 2010. The specimen was then transferred to resin to observe the left side, following Toombs' and Rixon's (1950) technique. Some vertebrae of the specimen and an impression of part of the axial skeleton were kept in the original slab. To obtain the positive of the impression, a cast was done. Unfortunately, the specimen was damaged during preparation and some bone fragments were lost. These are identified in the description below. Photographs were taken before and after preparation of the specimen. The head was also coated with ammonium chloride in order for photographs to be taken with a SONY Cybershot DSC-H100 camera. Drawings were made using a Leica MZ6 stereomicroscope with a camera lucida attachment.

\subsection{Terminology, measurements, and classification used}

Highest teleostean ranks (e.g., infraclass) follow Betancur et al. (2017) and the understanding of the family Pachyrhizodontidae follows current knowledge based on Forey (1977), Cavin (2001), Arratia (2008a), and Arratia and Tischlinger (2010). Osteological nomenclature follows Arratia (1997) for cranial bones, except those of the skull roof, which are based on the homology terminology for fishes as proposed by Jollie (1962) and Schultze (2008) for fishes. For other literature concerning this subject, see Schultze (2008). Traditional skull roof terms are given with the homologous ones in each figure.

Measurements were taken with a digital caliper Starret 799. The head length used in descriptions and comparisons was measured from the anterior margin of the lower jaw to the posterior margin of the opercular region. Orbital diameter and preorbital length were also expressed as percentages 


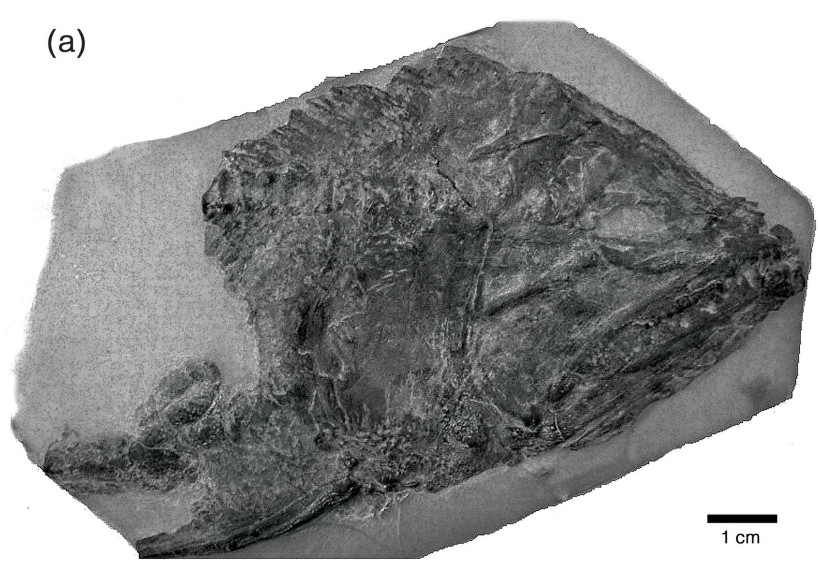

(b)

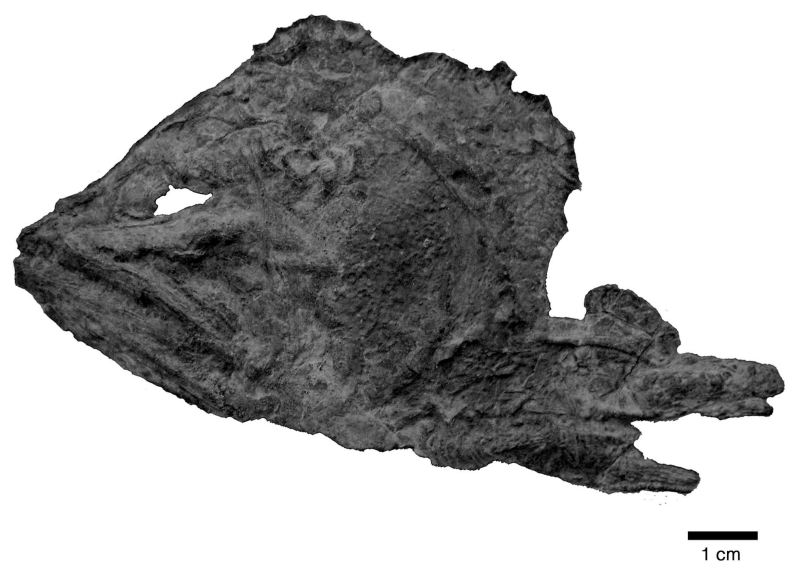

Figure 3. Motlayoichthys sergioi $\mathrm{n}$. gen. et n. sp. (a) Photograph of the right side of the holotype UAHMP-600 included in wax during the transfer process to resin; (b) Photograph of the left side of the holotype UAHMP-600 after preparation with the transfer method.

of the head length. The preorbital length was measured from the anterior border of the premaxilla to the anterior margin of the orbit. Orbital diameter was measured as the maximum width of the orbit.

\section{Systematic Paleontology}

Infraclass Teleostei Müller, 1845, sensu Arratia, 1999

Order Crossognathiformes Taverne, 1989, sensu Arratia 2008a

Suborder Pachyrhizodontoidei Forey, 1977

Family Pachyrhizodontidae Cope, 1872, sensu Forey 1977

Genus Motlayoichthys n. gen.
Content: Type and only species, Motlayoichthys sergioi n. sp.

Diagnosis: The same as for species.

Motlayoichthys sergioi $\mathrm{n}$. sp.

Figures 3-9.

Synonyms

2005 Salmoniform, González-Rodríguez and Bravo-Cuevas, p. 36, fig. 5E.

2016 Pachyrhizodus sp., González-Rodríguez et al., p. 114, fig. 3E.

Diagnosis: Pachyrhizodontid characterized by the following unique combination of characters (autapomorphies are identified with an asterisk in brackets): Head almost triangular-shaped with nearly equal sides and its maximum depth at the supraoccipital level [*]; small orbit, approximately $15 \%$ of head length; a short preorbital length, about $15 \%$ of head length; cranial bones densely ornamented with long, narrow longitudinal crests; pterotic with a well-developed posterior spine; large and squarish-shaped extrascapular bone [*]; large orbitosphenoid forming an almost complete septum separating both orbital cavities [*]; expanded postero-dorsal infraorbital plate reaching the anterior region of the opercle; lower jaw extending anterior to premaxilla [*]; supramaxilla long and narrow, covering a length equivalent to ca. $50 \%$ of the maxilla length; narrow maxilla with curvature along its ventral border [*] and posterior region of maxilla postero-ventrally inclined [*]; quadrate-mandibular articulation posterior to the posterior margin of orbit; premaxillary, maxillary, and dentary teeth with acrodin tips irregularly ornamented with fine, short striae and deep, elongated grooves; and dorsal fin anteriorly placed, closer to the posterior margin of head than middle body region.

Etymology: Genus name comes from the word "decorated, ornamented" (= Motlayolo) in the Mexican Náhuatl language; and the species name is sergioi in honor of the worker of the Muhi Quarry who discovered the specimen (Sergio Yáñez).

Holotype: UAHMP-600 (Figs. 3-9) consists of the head (ca. $150 \mathrm{~mm}$ length), the pectoral fins, several vertebrae and the impression of the anterior portion of the dorsal fin support, as well as several ribs and neural spines of the abdominal region. A section of the digestive tract is preserved (Figs. 3, 4).

Formation and age: The La Negra Facies of the El Doctor Formation. Albian-Cenomanian age (Bravo-Cuevas et al., 2009). 
Description: As a result of preparation, some fragments were lost; thus, there are slight differences in the length of some bones between the left and right sides of the head, for instance the anterior tip of the dentary. The head outline is nearly an equilateral triangle, with a sharp tip anteriorly at the level of the premaxilla and dentary, with the latter slightly projected rostrad (Figs. 3-5).

Skull: The head is preserved in lateral view (Figs. 3, 4). The cranial bones are completely ornamented with striations that make the identification of articulations difficult. The parietal bone (=frontal bone of traditional terminology) is elongated and widens posteriorly, whereas the post-parietal (= parietal bone of traditional terminology) is a small bone with a rectangular shape. Due to conditions of preservation, it is not possible to observe if the postparietals are separated by the supraoccipital or not. The small supraoccipital is incompletely preserved dorso-medial to the extrascapula (see Figs. 4a, b, 5). The massive, slightly triangular autosphenotic projects latero-ventrally as a prominent spine forming the postero-dorsal margin of the orbit. The pterotic is rectangular in shape and possesses a sharp postero-ventral process or spine extending posterior to the articular facet for the hyomandibula. The posterior border of the pterotic articulates with a large, square extrascapula, which is triangular-shaped in the majority of the family members. The surface of the right extrascapula presents short longitudinal crests of different lengths that radiate from the center of the bone. Its medial border is in contact with the supraoccipital. No sensory canals and pores are visible on the skull roof bones due to their thickness and ornamentation.

Part of the parasphenoid is preserved at the ventral portion of the braincase. The preserved portion is elongated, thin, and toothless. A thin interorbital septum (Figs. 4a, b, 5) formed by the orbitosphenoid separates both orbits almost completely. A well-developed basisphenoid is present, but a basipterygoid process is absent.

Circumorbital series: The orbit is small, ca. $15 \%$ of the head length. It is located in an anterior position in the head (preorbital length is ca. $15 \%$ of the head length). The circumorbital series (Figs. 3-5) seems to be closed anteriorly, but apparently has a small opening at the level of the autosphenotic, because its spine projects latero-ventrally, separating the antero-dorsal and postero-dorsal circumorbital regions. The dermosphenotic is incompletely preserved over the left autosphenotic, whereas its posterior portion is preserved on the right side of the cranium (Fig. 4). The region between the lateral margin of the cranium and the dorsal margin of the infraorbital plate $2+3+4+5$ (left side) is partially destroyed leaving a broad space, suggesting a large dermosphenotic. The circumorbital series is comprised of a supraorbital bone and two large plates (Figs. 4, 5) that are interpreted as the result of fusion of infraorbitals $1+2$ and $3+4+5$ by comparison to pachyrhizodontids with unfused infraorbitals, such as Goulmimichthys arambourgi (after Cavin, 2001) and Pachyrhizodus salmoneus (after Wenz and Fricot, 1985). However, the opposite side of the specimen (Figs. 4b, 5) suggests a broader fusion including infraorbitals 2-5. The lower part of the infraorbital series reaches the anterior margin of the preopercle, whereas the upper part extends onto the preopercle and reaches the anterior region of the opercle (Figs. 4b, 5). The two infraorbital plates are densely covered by long, very narrow crests (Figs. 3-7). The trajectory of the infraorbital canal (and its pores) is not visible due to the thickness of the bones and their ornamentation.

The supraorbital bone is triangular in shape, with a broad antero-ventral portion and a narrow postero-dorsal portion; ventro-anteriorly it is in contact with the plate formed by infraorbitals $1+2$ or infraorbital 1 alone and with the dermosphenotic posteriorly. An independent antorbital bone is not present, as in other crossognathiforms; it is unclear whether the antorbital is fused with infraorbital 1 or is absent. The sclerotic bones are not preserved.

Upper jaw: The premaxilla (Figs. 3, 4, 8) is somewhat rectangular-shaped, and no ascending process is observed. The lateral surface of the bone is ornamented with thin crests of various lengths. A row of a few large, slightly recurved teeth is preserved in the oral margin. This row's teeth are slightly different in size. The premaxillary internal tooth (Fig. 8a), characteristic of pachyrhizodontids, is located medial to the external teeth; it is larger, approximately twice the size of the external teeth, and more curved.

The tips of the teeth, where the preservation permits observation, have their acrodin cups ornamented with longitudinal striae. This kind of tooth has not been previously reported in the jaws of any pachyrhizodontoid species. Additionally, one to three deep grooves are observed in the lateral surface of some of premaxillary teeth.

The maxilla (Figs. 3-5) is approximately rectangular in shape with its posterior region curved ventrally and a concave ventral margin in its posterior half. Parallel longitudinal striae apparently cover the whole bony surface, although they are incompletely preserved or damaged in the holotype. A single row of about 10 straight and conical teeth, slightly smaller than those of the premaxilla, are observed in the left side of the head; three teeth are present anteriorly, and nine teeth posteriorly. The posterior teeth are closer to each other and wider than the anterior ones. The rest of the teeth are not preserved. The right side of the head shows about 12 teeth slightly smaller than those of the premaxilla in the anterior portion. Each tooth has an acrodin tip similar to the one in the premaxillary teeth. The supramaxilla (Figs. 4a, b, 5 ) is an elongated bone at the postero-dorsal margin of the maxilla and occupies about $50 \%$ of the length of the maxilla.

Lower jaw: The position of the anterior tip of the 
(a)

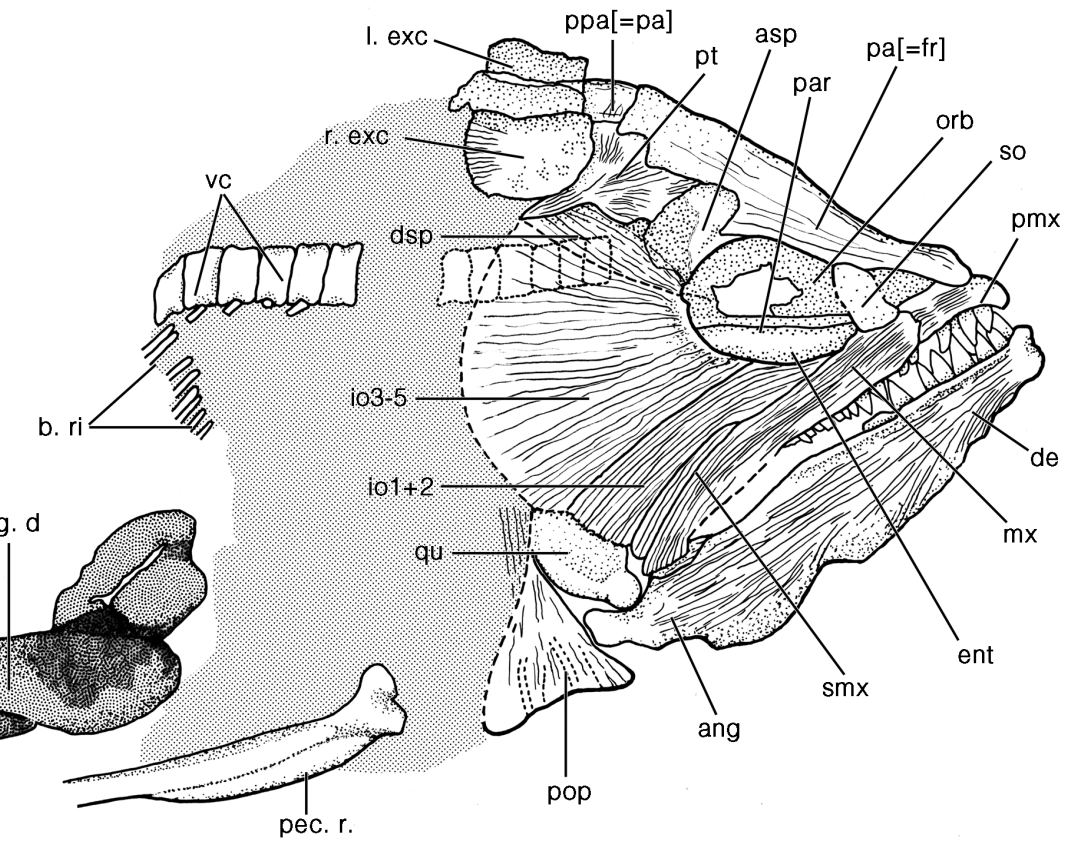

(b)

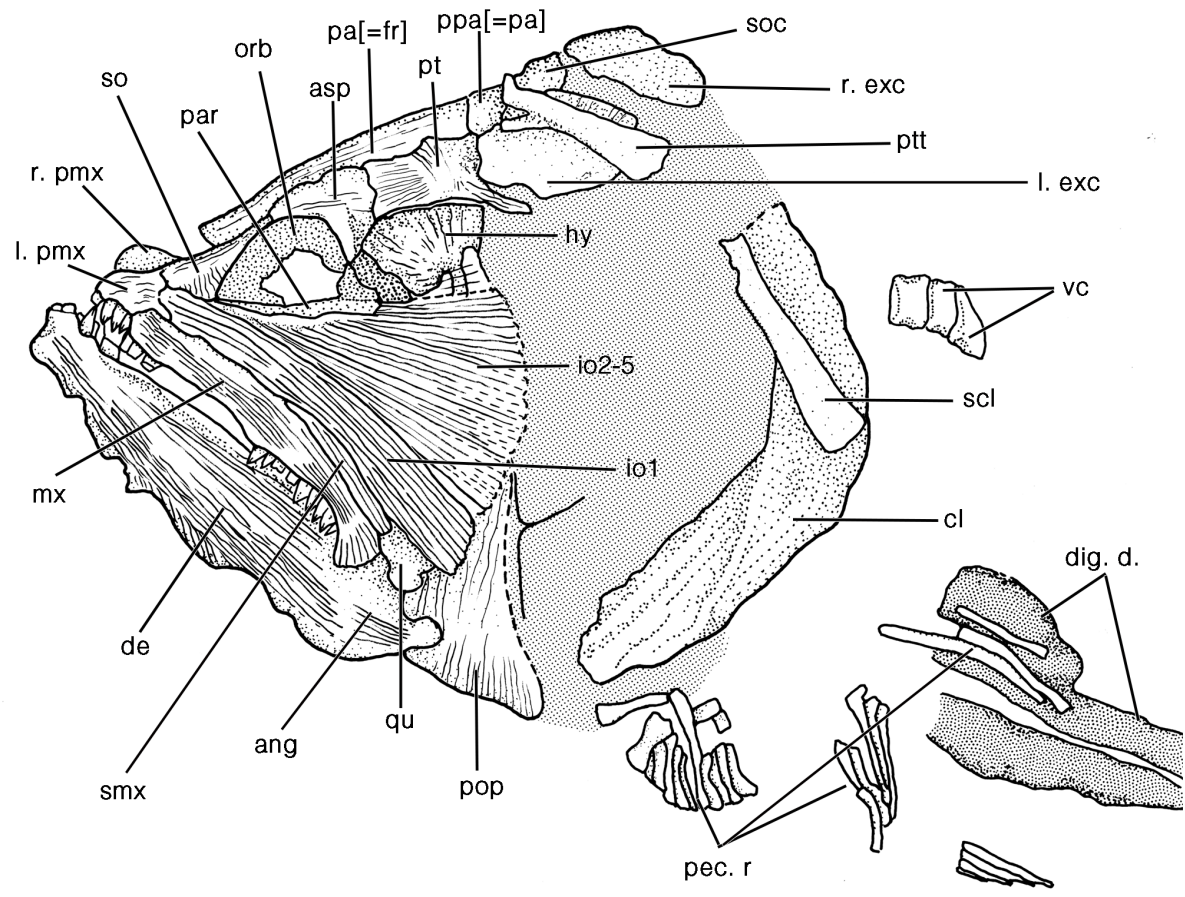

Figure 4. Motlayoichthys sergioi n. gen. et n. sp. (a) Drawing of the right side of the head, some abdominal vertebrae, and a section of the digestive duct of the holotype UAHMP-600. (b) Drawing of the left side of the head and part of the pectoral girdle. Dotted sections indicate an area covered by sediment. Abbreviations: ang, angular; asp: autosphenotic; b.ri: broken ribs; cl: cleitrum; de: dentary; dig.d: section of digestive duct; dsp: broken and displaced dermosphenotic; ent: entopterygoid; hy, hyomandibula; io: infraorbital bones; l.exc: slightly displaced left extrascapula; 1.pmx: left (broken) premaxilla; mx: maxilla; orb: orbitosphenoid; pa[=fr]: parietal bone; ppa[= pa]: postparietal bone; par: parasphenoid; pec.r: pectoral rays; pop: preopercle; pmx: premaxilla; pt: pterotic; ptt: displaced posttemporal; qu: quadrate; r.exc: slightly displaced right extrascapula; r.pmx: right (broken) premaxilla; scl: supracleitrum; so: supraorbital bone (broken and displaced in a); soc: supraoccipital; smx: supramaxilla; vc: abdominal vertebral centra. 


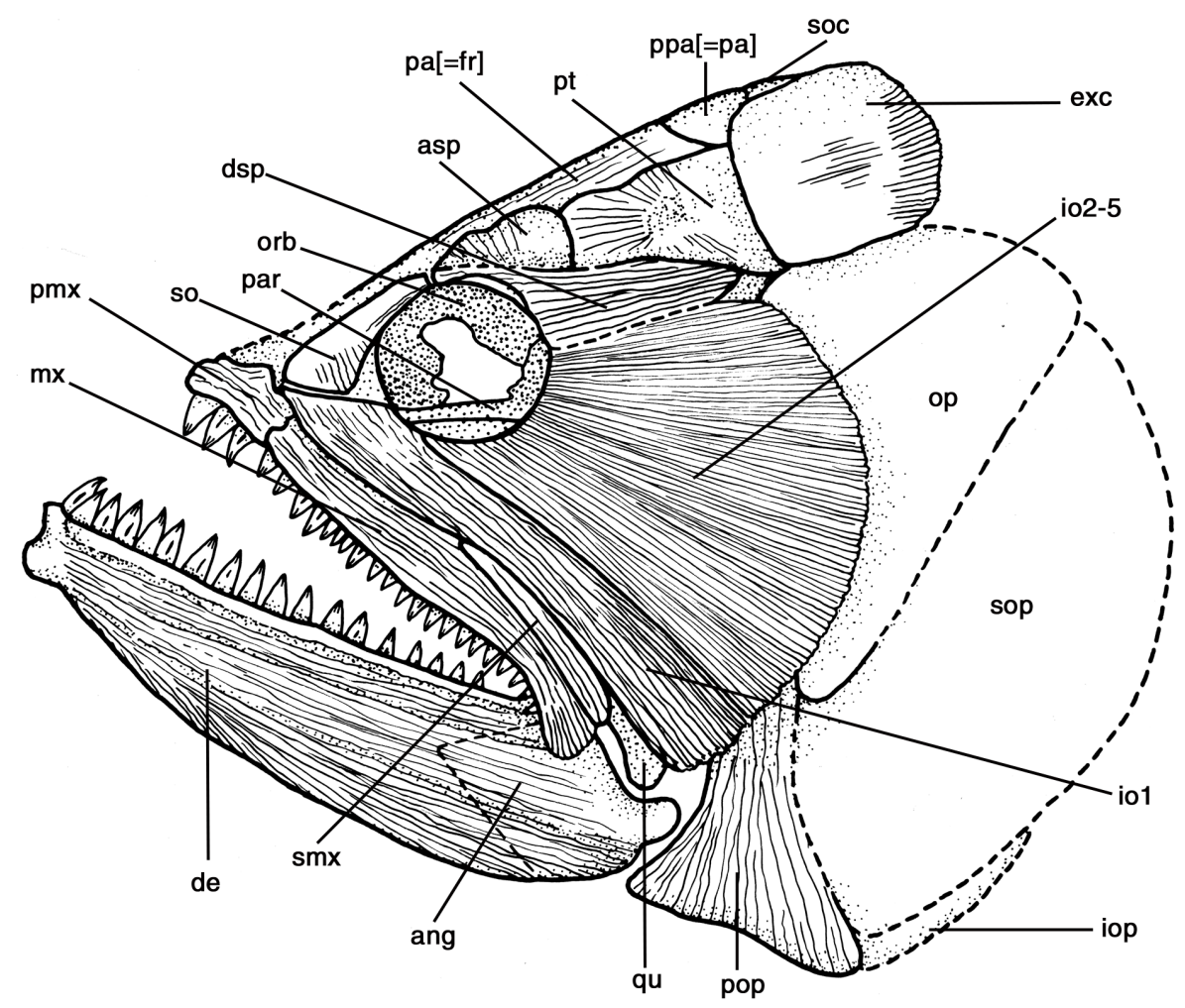

Figure 5. Reconstruction of Motlayoichthys sergioi n. gen. et n. sp. Abbreviations: ang: angular; asp: autosphenotic; de: dentary; dsp: dermosphenotic; exc: extrascapula; io: infraorbital bone; iop: interopercle; mx: maxilla; orb: orbitosphenoid; op: opercle; pa[=fr]: parietal bone; par: parasphenoid; pmx: premaxilla; pop: preopercle; ppa[= pa]: postparietal bone; pt: pterotic; qu: quadrate; smx: supramaxilla; so: supraorbital bone; soc: supraoccipital; sop: subopercle.

lower jaw - anterior to the premaxilla - gives the fish a characteristic aspect (Fig. 5) that differentiates it among pachyrhizodontids where the anterior ends of the dentary and premaxilla are at (or nearly at) the same level. Laterally, the lower jaw is formed by the dentary and the angular. The dentary (Figs. 3-5) is narrower close to the symphysis and almost rectangular posteriorly, with the oral and ventral borders almost parallel along their lengths so that a coronoid process is not developed. The dentary is approximately $58 \%$ of the head length. Its lateral surface is ornamented with fine, longitudinal crests running parallel to the bone borders. The dentary presents a single row of teeth that are incompletely preserved in both jaws. The right dentary has eight conical teeth preserved, whereas the left jaw has seven preserved; they are larger (Fig. 8b) than those of the maxilla and exhibit acrodin tips that are not well exposed in the specimen. They may bear a deep groove on their exposed surfaces. The lateral portion of the angular with a well-developed postarticular process is preserved. The suture between the angular and dentary is partially obscured by the longitudinal crests extending along the bony surface. The presence of a retroarticular bone has not been observed, because the postero-ventral corner of the jaw is damaged.
Hyopalatine series: The hyomandibula has a simple and broad articular head with the cranium, but its posterior opercular process is not preserved; its ventral region is long and narrow (Fig. 4b), and forming an angle of about 90 degrees with respect to the body axis. The quadrate, that is incompletely exposed, is triangular in shape, with a large articular condyle. The entopterygoid is partially exposed in the right side of the specimen, no teeth or sockets for teeth are visible. Other bones of the hyopalatine series are not visible, because they are covered by the infraorbitals.

Opercular series, branchiostegal rays, and gular plate: The opercular series is not clearly visible on either side of the specimen, because it is partially covered by the distal tip of postero-dorsal infraorbital plate, and the posterior margins of the opercle and subopercle are weathered and partially covered by sediment. The shape of the preopercle is unclear. Part of the ventral limb of the preopercle is observed with the postero-ventral portion moderately expanded and markedly inclined postero-ventrally (Figs. 3-5). There are at least four branches of the preopercular sensory canal in the ventral limb (Fig. 4). The preserved sutural region between opercle and subopercle (Fig. 4b) and the restoration of the region show that the subopercle seems to be larger 

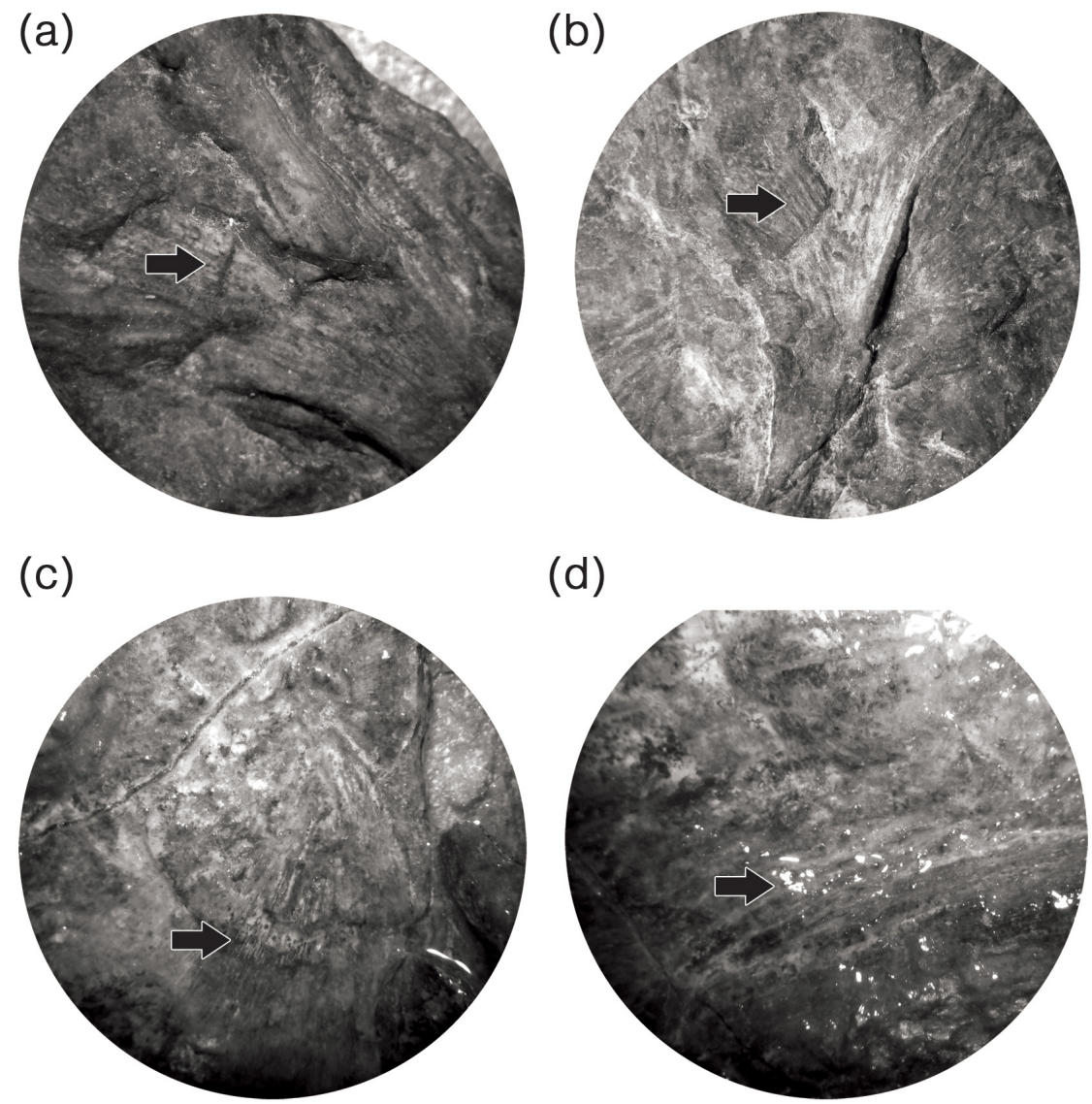

Figure 6. Photographs showing the ornamentation of bones in the head of Motlayoichthys sergioi n. gen. et n. sp. Arrows point to the ornamentation on (a) the parietal bone ( $\mathrm{pa}[=\mathrm{fr}])$; (b) pterotic; (c) preopercle; and (d) narrow crests extending along the bony surface of the infraorbital bones.

(a)

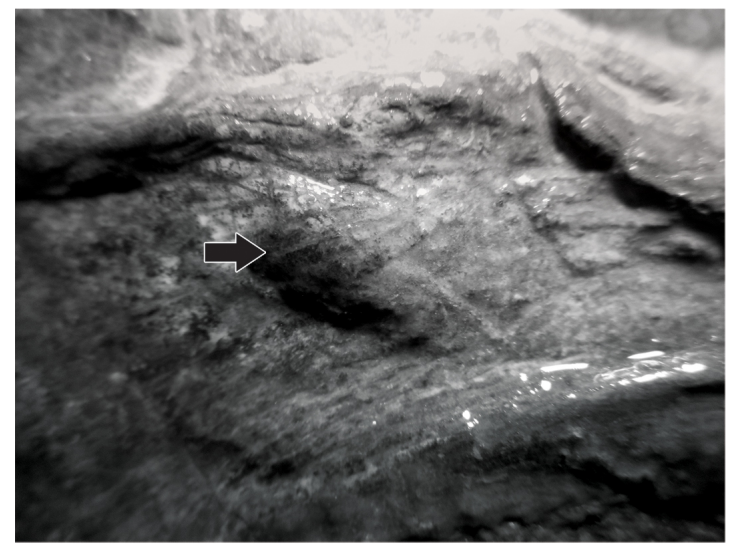

(b)

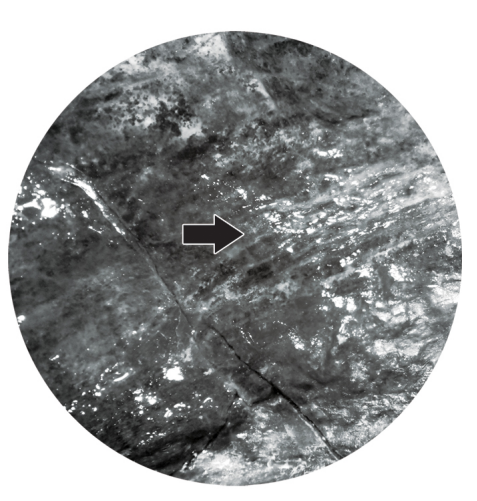

Figure 7. Motlayoichthys sergioi $\mathrm{n}$. gen. et n. sp. (a) Close-up view of a section of the infraorbital plate io $3+$ io $4+$ io5 (right side of head); (b) close view of a section of the infraorbital plate io $1+$ io 2 (right side of head). Arrows point to the narrow crests that extend along the bony surface. 
(a)

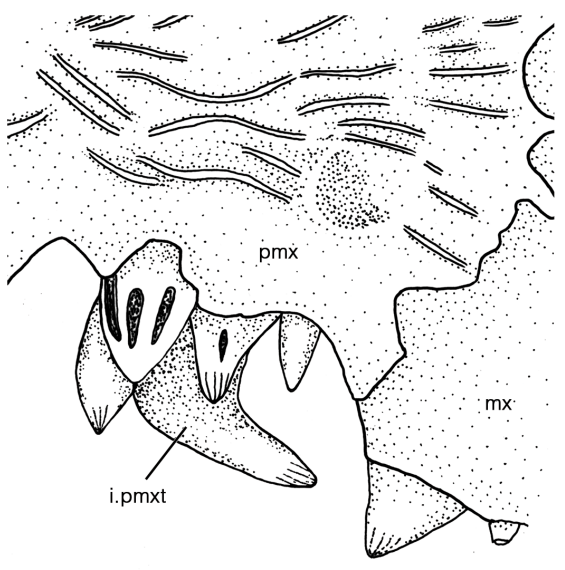

$1 \mathrm{~cm}$

(b)

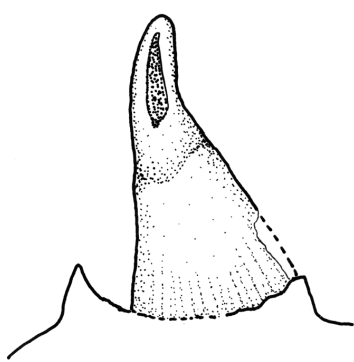

Figure 8. Drawing of a region of the premaxilla of Motlayoichthys sergioi $\mathrm{n}$. gen. et $\mathrm{n}$. sp., showing premaxillary teeth with acrodin tips and ornamentation, the inner premaxillary tooth (a), and a dentary tooth (b). Abbreviations: i.pmxt: inner premaxillary tooth; mx: maxilla; pmx: premaxilla.

than the opercle (Fig. 5). The interopercle is not preserved. No branchiostegal rays are preserved. A gular plate is not present between the lower jaws.

Vertebral column: Forty-seven well-ossified, narrow vertebral centra with a height of ca. $10 \mathrm{~mm}$ are preserved (Figs. 4, 9). They were kept in the original slab during preparation, and 22 vertebrae remained articulated with the head (Fig. 4). The centra are smooth with no ridges or grooves on their lateral surfaces. The neural arches and spines seem to be particularly narrow, because there is not a marked difference between them in the preserved vertebral column. The neural arches seem to be autogenous; however, it is not possible to clarify whether the neural spines are simple or double. The impression of long and narrow neural spines is seen behind the head and along the vertebral series. Although ribs are not preserved, their impressions are observed associated with the first 43 vertebrae. The ribs are slender with their proximal bases slightly expanded. Remains of some epineurals lie above centra 28 to 36 . They are slender and long, extending about the length of five centra. Some remains of epipleurals are present in the abdominal region; they are more evident from vertebrae
26 to 38. A few long narrow bones lie below and lateral to some centra. We interpret these elements as displaced ribs.

Pectoral girdle and fin: During the chemical and mechanical preparation of the specimen, some fragments of the posttemporal, cleithrum and supracleithrum were lost; nevertheless, it is still possible to observe that incomplete cleithrum has a boomerang form. The antero-dorsal border of the cleithrum is covered by the supracleithrum, which is a straight, elongated, and narrow bone (Fig. 4b), whose dorsal region is incompletely preserved. Some striae running parallel to the postero-ventral portion of the supracleithrum are observed. Dorsal to the supracleithrum is a displaced posttemporal lying on the extrascapula (see Fig. 4). Although the bone is missing part of its anterior region, it is possible to see that the posttemporal is an elongate bone.

The pectoral fin, which has a low position in the flank (Figs. 3, 4, 9), consists of 10 unbranched rays distally segmented. The outermost ray is wider than the rest and is spine-like. It is a compound element like that present in many primitive teleosts and a few recent ones (e.g., elopiforms) - as described by Arratia (2008b, 2009). Four pectoral proximal radials (Fig. 9) are incompletely preserved, they are displaced near the pectoral fin.

Dorsal fin: The dorsal fin is incompletely preserved so that its total length and size is unknown. At the level of the 13th vertebra, the impression of 12 long and slender proximal radials is observed on the original slab (Fig. 9), suggesting an anterior position of the dorsal fin in the trunk. The first pterygiophore presents a slight expansion proximally; the rest are narrow bones. There is an equal number of small middle radials lying above the proximal ones, but at least seven more middle radials are located behind these associated with preserved proximal radials. It is possible that the fin continued posteriorly, as occurs in Pachyrhizodus caninus (Shimada, 2015) and Tingitanichthys heterodon (Taverne, 1996) that have a similar, anteriorly positioned dorsal fin. The pelvic, anal, and caudal fins are not preserved.

\section{Taxonomic affinities and comparisons}

Even though up until now only one incomplete specimen of the taxon described here has been found in the Muhi Quarry, the study of the skull bones and postcranial skeleton of the specimen allowed its taxonomic assignation as a new genus and species. Motlayoichthys sergioi $\mathrm{n}$. gen. et $\mathrm{n}$. sp. presents the following characters that are interpreted as synapomorphies of the order Crossognathiformes: a large and welldeveloped extrascapular bone, toothless parasphenoid, and an absent gular plate (Arratia, 2008a; Arratia and Tischlinger, 2010). Other features such as the roofing of the posttemporal fossa, the retroarticular excluded from the articular facet for 


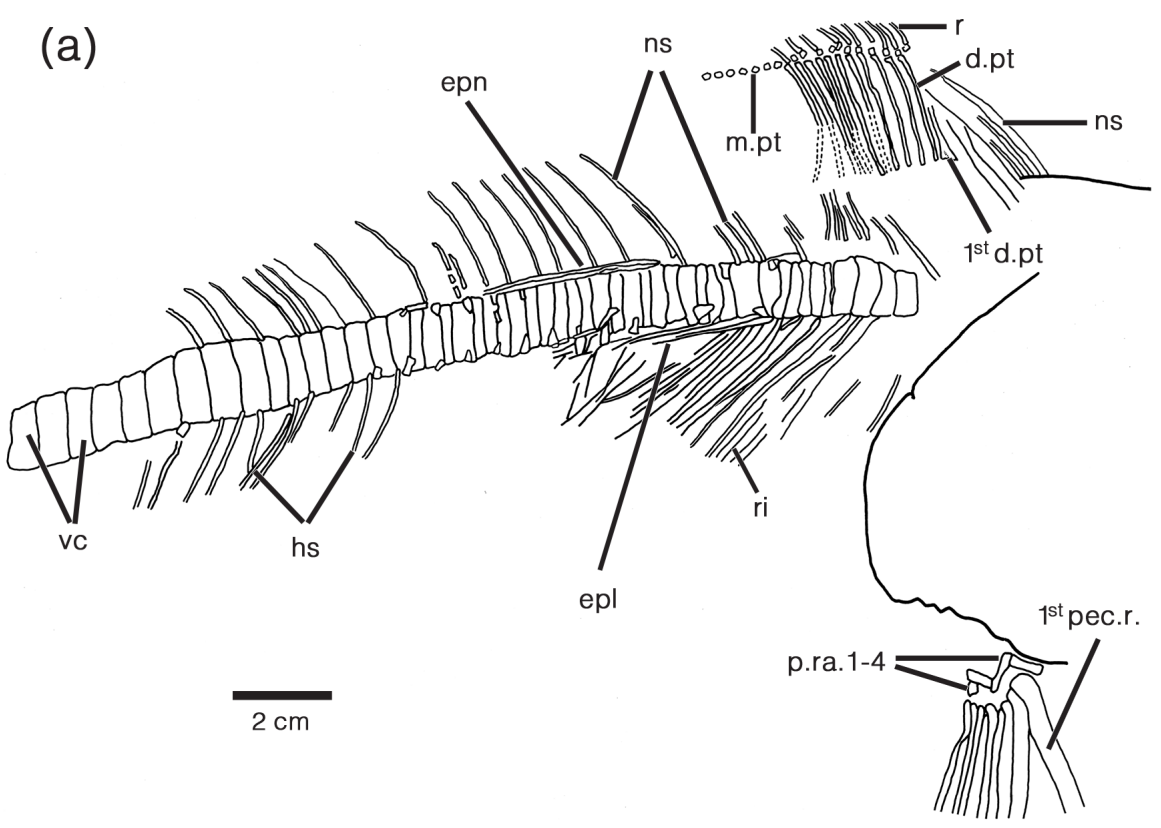

(b)

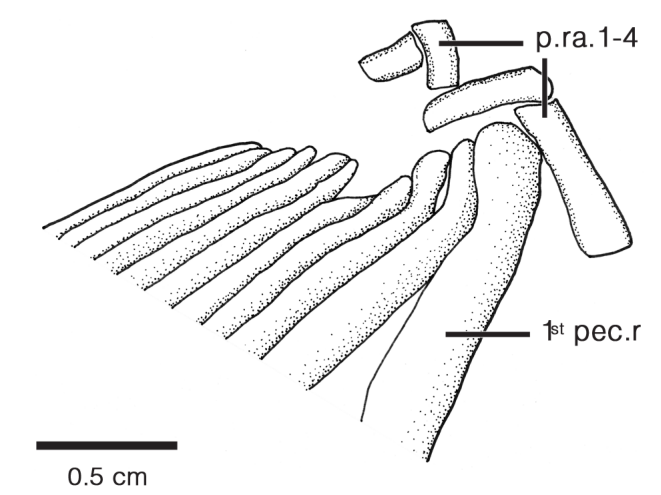

Figure 9. Motlayoichthys sergioi $\mathrm{n}$. gen. et $\mathrm{n}$. sp. (a) Impression of the abdominal vertebral region partially preserved in the slab, and of the dorsal and pectoral fins; (b) drawing of the left pectoral fin. Abbreviations: d.pt: dorsal pterygiophores; epl: epipleurals; epn: epineurals; hs: haemal spines; m.pt: middle radials; ns: neural spines; p.r: pectoral ray; p.ra: pectoral proximal radials; r: dorsal rays; ri: ribs; vc: vertebral centra.

quadrate, and an acuminate dorsal fin cannot be determined because of incomplete preservation. Motlayoichthys sergioi n. gen. et $\mathrm{n}$. sp. shares numerous characters with members of the suborder Pachyrhizodontoidei e.g., the presence of an orbitosphenoid and a basisphenoid, a hyomandibula with a single articulatory head, a premaxilla with small dorsal process, a single row of maxillary teeth, a single, splint-like supramaxilla, a well-developed postarticular process in the lower jaw, absence of a basipterygoid process, no separate antorbital, and a pectoral fin positioned low on the flank (Forey, 1977).

Motlayoichthys sergioi $\mathrm{n}$. gen. et $\mathrm{n}$. sp. shares with members of the family Pachyrhizodontidae (Forey, 1977) a long parietal bone ( $=$ frontal of traditional terminology) with the lateral margin excavated above the autosphenotic spine and in having an internal premaxillary tooth present. Although the fusion of certain infraorbital bones has been interpreted as a pachyrhizodontoid character (Forey, 1977), not all genera described and/or illustrated in the literature share this character (see Fig. 10a, b). It also shares with other pachyrhizodontoids a quadrate-mandibular articulation placed posterior to the posterior margin of the orbit (Arratia and Tischlinger, 2010).

A revision of the pachyrhizodontid genera was done to compare with the new pachyrhizodontid from Muhi Quarry, and though we found some similarities, the new genus does 
(a)
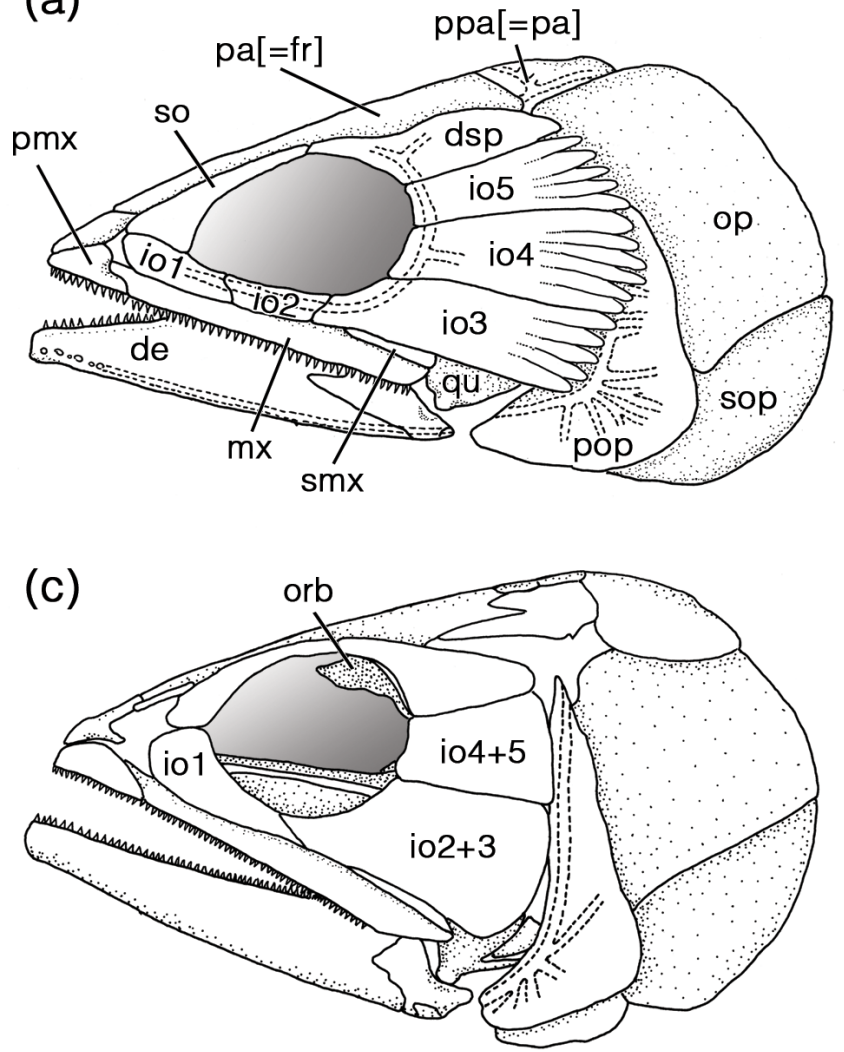

(b)

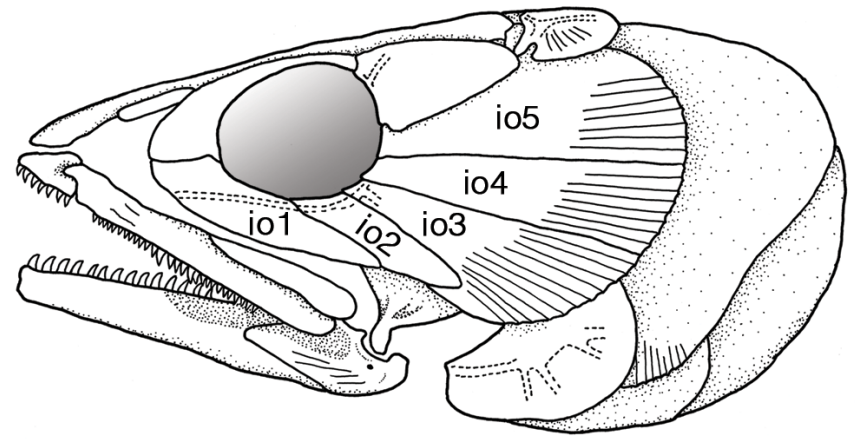

(d)

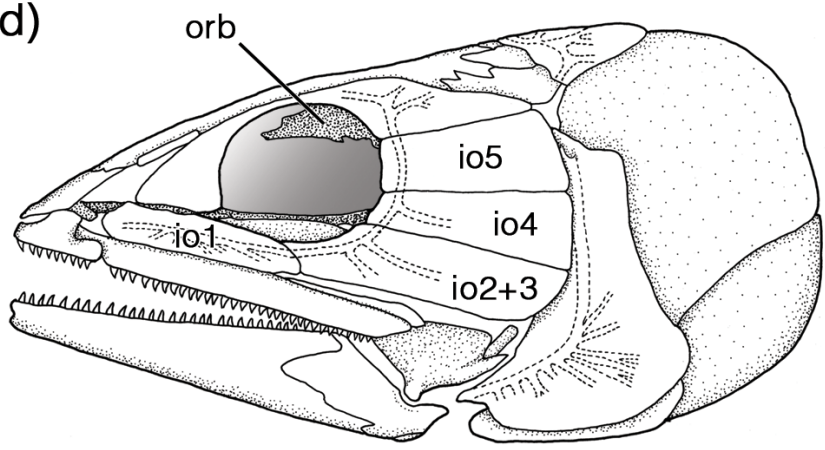

Figure 10. Heads in lateral view of certain pachyrhizodontoids. (a) Pachyrhizodus salmoneus (modified from Wenz and Fricot, 1985), (b) Goulmimichthys arambourgi (modified from Cavin, 2001), (c) Notelops brama (slightly modified from Forey, 1977), and (d) Rhacolepis buccalis (slightly modified from Forey, 1977). Abbreviations: de: dentary; dsp: dermosphenotic; io1-5: infraorbitals 1-5; mx: maxilla; op: opercle; $\mathrm{pa}[=\mathrm{fr}]$ : parietal bone [ $=$ frontal of traditional terminology]; pmx: premaxilla; pop: preopercle; qu: quadrate; $\mathrm{ppa}=\mathrm{pa}]$ : postparietal bone [= parietal of traditional terminology]; so: supraorbital bone; smx: supramaxilla; sop: subopercle.

exhibit a unique combination of characters and several autapomorphies (see Diagnosis); for instance: the head shape is nearly an equilateral triangle, whereas other pachyrhizodontids (and also Notelops) have an elongate head (Fig. 10a-d), as do the oldest crossognathiforms, Chongichthys (Jurassic: Oxfordian; Arratia, 1982, 2008a) and Bavarichthys (Jurassic: Kimmeridgian?; Arratia and Tischlinger, 2010). An exception is Tingitanichthys (Cretaceous) with a short and deep head (Taverne, 1996). The lower jaw extending anterior to the premaxilla is a unique feature of Motlayoichthys sergioi $\mathrm{n}$. gen. et $\mathrm{n}$. sp. In the remaining pachyrhizodontoids, the jaws end at the same level (compare Figs. 5 and 10). The characteristic maxilla of Motlayoichthys sergioi $\mathrm{n}$. gen. et n. sp. has a concavity in the posterior half of its ventral border, and its posterior tip is inclined ventrally, whereas in other pachyrhizodontoids the maxilla is narrow, with straight dorsal and ventral margins.

Motlayoichthys sergioi $\mathrm{n}$. gen. et $\mathrm{n}$. sp. possesses an almost complete interorbital septum (Figs. 4a, b, 5), separating both eyes. Apparently, Michin scernai also has a nearly complete septum (Citlalli Hernández-Guerrero, personal observation, October 2013). A reduced interorbital septum (Fig. 10d) is present in Rhacolepis buccalis (Forey, 1977: figs. 13, 20) and also in the Jurassic genera Chongichthys (Arratia, 1982: fig. 4) and Bavarichthys (Arratia and Tischlinger, 2010: fig. 5). It is unclear whether the bone is reduced in size in other pachyrhizodontids, because it has not been mentioned or illustrated in the literature - the bone is frequently damaged because of its thinness. The circumorbital ring seems to be completely closed in pachyrhizodontids such as Pachyrhizodus salmoneus (Fig. 10a), Rhacolepis buccalis (Fig. 10d), and Goulmimichthys (Fig. 10b) species, as well as in the notelopid Notelops brama (Fig. 10c), whereas the ring is open at the level of the autosphenotic in Motlayoichthys sergioi. The condition is unclear in Michin due to incomplete preservation.

Motlayoichthys sergioi has a small orbit occupying ca. $15 \%$ of its head length, the smallest among pachyrhi- 
zodontids such as Goulmimichthys arambourgi (ca. 19\%; see Fig. 10b) and Goulmimichthys gasparini (Páramo-Fonseca, 2001), Rhacolepis buccalis (ca. 20\%; Fig. 10d), Pachyrhizodus salmoneus (ca. 25\%; Fig. 10a), and Michin scernai (ca. 25\%; Alvarado-Ortega et al., 2008), and the notelopid Notelops brama (about $24 \%$; see Fig. 10c). Additionally, the preorbital length of Motlayoichthys sergioi n. gen. et n. sp. (ca. $15 \%$ of head length) and of Pachyrhizodus salmoneus (ca. $17 \%$ ) are considerably shorter than that of Aquilopiscis wilsoni, Goulmimichthys species, Rhacolepis buccalis, and Michin scernai (which are about $25 \%$ of head length).

Heavily ornamented cranial bones covered by long striae and/or longitudinal crests characterize Motlayoichthys sergioi n. gen. et n. sp. (see Figs. 4-7). Similar striae are present in Pachyrhizodus minimus (KUVP-300), Rhacolepis buccalis (Voltani and Bertini, 2012), and P. caninus (FHSM VP-218; Citlalli Hernández-Guerrero, personal observation, November 2013), with the ornamentation located only on the jaw bones and parietals. Apparently, this is a character unique to these species among pachyrhizodontids. The premaxilla of $P$. caninus from Vallecillo, Mexico is almost completely covered by well-defined striae (Giersch et al., 2010b: fig. 4, photograph).

Motlayoichthys sergioi $\mathrm{n}$. gen. et $\mathrm{n}$. sp. is interpreted here as having the infraorbital bones fused into two asymmetric plates (infraorbital $1+2$ and 3-5 on the right side of the head and io1 and io2-5 on the left; Fig. 4). Infraorbitals $2+3$ and $4+5$ are interpreted as fused in the notelopid Notelops brama by Forey (1977; see Fig. 10c), and in the pachyrhizodontids Tingitanichthys by Taverne (1996) and Michin scernai by Alvarado-Ortega et al. (2008: fig. 2c). However, a suture between infraorbitals 4 and 5 was observed during examination of the holotype of Michin scernai (Citlalli Hernández-Guerrero, personal observation, October 2013). In contrast, all infraorbital bones are independent in pachyrhizodontids such as Goulmimichthys (Fig. 10b); Cavin, 2001; Páramo-Fonseca, 2001), Greenwoodella tockensis (Taverne, 1973), Pachyrhizodus megalops (Forey, 1977), Pachyrhizodus salmoneus (Fig. 10a: Wenz and Fricot, 1985), and Pachyrhizodus etayoi (PáramoFonseca, 2001).

The occurrence of conspicuous longitudinal crests on the infraorbital bones is a feature shared with Goulmimichthys arambourgi (Cavin, 2001), Pachyrhizodus salmoneus (Wenz and Fricot, 1985), Pachyrhizodus etayoi (interpretation of photographs kindly provided by María Eurídice Páramo Fonseca), and the crossognathiform Crossognathus sabaudianus (Taverne, 1989). Moreover, we have observed that the infraorbital crests can be tenuous and narrow or pronounced and wide, running along the bone, or running only from the middle portion of the bone to the posterior part. Wide crests in the posterior half of infraorbitals 3, 4 and 5, which are different from those present in Motlayoichthys sergioi n. gen. et n. sp., have been observed in speci- mens assigned to Pachyrhizodus minimus (KUVP-300 and KUVP-36032). A review of the literature revealed the presence of wide interdigitations in Goulmimichthys arambourgi (Cavin, 2001), Pachyrhizodus salmoneus (Wenz and Fricot, 1985), Pachyrhizodus etayoi (Páramo-Fonseca, 2001), and the crossognathiform Crossognathus sabaudianus (Taverne, 1989).

Most pachyrhizodontoids possess jaws bearing many teeth of similar sizes, generally small (see for instance Fig. 10ad), a condition also observed in the Jurassic forms (see Arratia, 1982: figs. 6, 8 for Chongichthys dentatus; Arratia and Tischlinger, 2010: fig. 5 for Bavarichthys incognitus). In contrast, teeth of different sizes are present in Michin scernai (Alvarado-Ortega et al., 2008: fig. 2), and apparently in Aquilopiscis wilsoni (Cumbaa and Murray, 2008: figs. 6B, 7-9). By comparison, the new fish here described presents fewer teeth, but they are larger in size (Figs. 4, 5). Acrodin tips bearing some characteristic striations and deep grooves along certain teeth seem to be unique to Motlayoichthys sergioi $\mathrm{n}$. gen. et $\mathrm{n}$. sp. However, Michin scernai seems to present some striae on the surface of the teeth (Citlalli Hernández-Guerrero, personal observation, October 2013). Tooth ornamentation seems to be more common in pachyrhizodontids than previously thought, as observed in Michin scernai (Citlalli Hernández-Guerrero, personal observation, October 2013) and in Aquilopiscis wilsoni (Cumbaa and Murray, 2008).

Apparently, a general pachyrhizodontoid condition is the presence of teeth ordered in one main row. Motlayoichthys sergioi $\mathrm{n}$. gen. et $\mathrm{n}$. sp. shares this character with other pachyrhizodontoids (see for instance Figs. 4, 5, 10). In contrast, Michin scernai bears three rows of teeth in the lower jaw (Alvarado-Ortega et al., 2008); however, only one row of teeth is observed in the holotype IGM- 9028 (Citlalli Hernández-Guerrero, personal observation, October 2013). The dentary of the Late Jurassic Bavarichthys incognitus has a platform-like oral margin covered with many small conical, villiform teeth (Arratia and Tischlinger, 2010: figs. 4C, 5), whereas the dentary teeth of the basal crossognathiform Chongichthys dentatus (from the Oxfordian of Chile) are small and conical in the outer row close to the symphysis and become larger posteriorly and in the inner rows (Arratia, 1997).

Motlayoichthys sergioi $\mathrm{n}$. gen. et $\mathrm{n}$. sp. has an elongate, styliform-like supramaxillary bone (Fig. 4) that is a diagnostic feature of pachyrhizodontoids after Forey (1977). The bone is about $50 \%$ of the length of the maxilla as in Goulmimichthys arambourgi (Fig. 10b), but it is shorter in other pachyrhizodontoids (e.g., Fig. 10). Two supramaxillae of different sizes were illustrated in some specimens of the notelopid Notelops by Maisey (1991b). Two supramaxillae are known in the Late Jurassic Bavarichthys, with supramaxilla 2 smaller than supramaxilla 1 (Arratia and Tischlinger, 2010: fig. 5). 
The dorsal fin position varies among pachyrhizodontoids; the fin can be located close to the head or far back and can extend almost the entire length of the trunk or be short. Although in Motlayoichthys sergioi $\mathrm{n}$. gen. et n. sp., the dorsal fin is not preserved, it is possible to observe it as an impression (see Fig. 9a) that starts at the level of the 13th vertebra, close to the head as occurs in Pachyrhizodus caninus (Shimada, 2015), in which the dorsal fin starts at the level of the 10th vertebra. This anterior position of the fin is also observed in Tingitanichthys heterodon (Taverne, 1996) in which it starts about the 11th vertebra. Moreover, Pachyrhizodus caninus and Tingitanichthys heterodon have long dorsal fins, with about 36 rays in the former, and three spines and 27 rays in the latter. The remaining pachyrhizodontoids present a triangular, short dorsal fin positioned about the middle length of the trunk or more posteriorly, for example, Michin csernai (Alvarado-Ortega et al., 2008: fig. 1) has a dorsal fin composed by 15 rays originated at about the 20th vertebra; Elopopsis microdon (Taverne, 1994) has 16 dorsal fin rays with the fin originating at the 27th vertebra; Platinx macropterus (Taverne, 1980) has a dorsal fin with two spines and 22 rays, originating at the 44th vertebra. Therefore, we suggest that Motlayoichthys sergioi n. gen. et n. sp. had a long dorsal fin according to its anterior position and the 22 medial radials preserved, perhaps similar to Pachyrhizodus caninus. Finally, we consider that the combination of characters present in Motlayoichthys sergioi strongly support its assignment as a new genus and species within the family Pachyrhizodontidae.

\section{Pachyrhizodontoids during the Lower Cretaceous (Albian)}

The oldest crossognathiforms are known from the Oxfordian of Chile (Arratia, 2008a, 2015) and from the Kimmeridgian of Germany (Arratia and Tischlinger, 2010), which certainly represent very distant locations and are interpreted as belonging to the Tethys realm. Biogeographic hypotheses suggest a connection between these distant places in the Northern and Southern Hemispheres through the so-called Hispanic Corridor that was formed by the separation of North and South America (Hallam, 1983; Aberhan, 2002; Porter et al., 2013). From that beginning, the pachyrhizodontids and relatives, apparently underwent a significant radiation during the Cretaceous with one genus known from the Aptian of Germany (Greenwoodella; Taverne, 1973) and five genera from the Albian time: the notelopid Notelops from Brazil (South America), and the pachyrhizodontids Rhacolepis from Brazil (South America) and Mexico (North America), Pachyrhizodus from England and France (Europe), as well as Queensland (Australia), and Michin and Motlayoichthys n. gen. from Mexico (North America). Of these genera, only Pachyrhizodus reached the Cenomanian (of United States; Shimada, 2015) and Turonian times (of United States, Mexico and
Colombia; Páramo-Fonseca, 2001; Alvarado-Ortega et al., 2006; Giersch et al., 2010b; González-Rodríguez et al., 2016). Tingitanichthys was first recovered in the Cenomanian of Morocco (Taverne, 1996) and more recently in the lower Turonian of Mexico (Giersch et al., 2010a; GonzálezRodríguez et al., 2016). Conversely, Goulmimichthys, is the youngest pachyrhizodontid, reported from the Turonian of Mexico (Blanco and Cavin, 2003). It is also known from the Turonian of Colombia (Páramo-Fonseca, 2001) and Morocco (Cavin, 2001). Another Turonian pachyrhizodontid, Aquilopiscis, is known only from the Northwest Territories of Canada (Cumbaa and Murray, 2008). According to the available information, the notelopid Notelops is endemic to Brazil (Forey, 1977; Maisey, 1991b), whereas the pachyrhizodontids Michin and Motlayoichthys n. gen. are endemic to Mexico. Rhacolepis, a genus that was previously considered as endemic to Brazil (e.g., Forey, 1977; Maisey, 1991a), was recently reported in Mexico by Espinosa-Arrubarrena and Alvarado-Ortega (2010). Currently, the Muhi Quarry is an important locality from where several fishes belonging to a broad array of teleostean groups are known from this locality: primitive teleosts such as the crossognathiform pachyrhizodontid Motlayoichthys sergioi n. gen. et sp., euteleosts such as the aulopiforms Ichthyotringa mexicana (Fielitz and González-Rodríguez, 2008) and Enchodus zimapanensis (Fielitz and González-Rodríguez, 2010), the stem acanthomorph Muhichthys cordobai (González-Rodríguez and Fielitz, 2008), and the miniature armored acanthomorphs, Handuichthys interopercularis, Pseudomonocentris microspinosus and Dalgoichthys tropicalis (GonzálezRodríguez et al., 2013b).

Data availability. All material included in the paper is accessible in the listed museums and all data are included in the descriptions.

Competing interests. The authors declare that they have no conflict of interest.

Acknowledgements. The authors thank Sergio Yañez, worker of the quarry for collecting the specimen that was named to honor his effort to conserve the fossil patrimony of the Muhi Quarry. We thank especially Jesús Alvarado-Ortega and María Eurídice Páramo-Fonseca who kindly made available photographs of Michin csernai and Pachyrhizodus etayoi, respectively. We thank María Carmen Perrilliat for permitting the third author to study fossil material deposited in the "Ma. Carmen Perrilliat" Museum of the Instituto de Geología, Universidad Nacional Autónoma de México and Hans-Peter Schultze for helping Citlalli HernándezGuerrero with the pachyrhizodontoid fish collection of the Division of Vertebrate Paleontology, Natural History Museum, University of Kansas, Lawrence. Erika Alonzo helped with the editing of figures. Terry J. Meehan checked the manuscript for grammar and style. Alison Murray and an anonymous reviewer provided interesting 
and helpful comments and criticisms.

Edited by: Torsten Scheyer

Reviewed by: Alison Murray and one anonymous referee

\section{References}

Aberhan, M.: Opening of the Hispanic Corridor and Early Jurassic bivalve biodiversity, in: Palaeogeography and biodiversity change: the Ordovician and Mesozoic-Cenozoic Radiations, edited by: Crame, J. A. and Owen, A. W., Geological Society, London, Special Publications, 194, 127-139 2002.

Agassiz, L.: On the fossil fishes found by Mr. Gardner in the province of Ceará, in the North of Brasil, Edinburgh New Philosophical Journal, 30, 82-84, 1841.

Alvarado-Ortega, J., Garibay-Romero, L. M., Blanco-Piñón, A., González-Barba, G. J., Vega, F., and Centeno-García, E.: Los peces fósiles de la formación Mexcala (Cretácico Superior) en el Estado de Guerrero, México, Rev. Brasileira Paleontol., 9, 261272, 2006.

Alvarado-Ortega, J., Mayrinck, D., and Brito, P.: A basal pachyrhizodontid fish (Actinopterygii, Teleostei) from the Lower Cretaceous of the Tlayúa Quarry, Central Mexico, C. R. Palevol, 7, 269-275, 2008.

Arratia, G.: Chongichthys dentatus, new genus and species from the Late Jurassic of Chile (Pisces, Teleostei, Chongichthyidae, new family), J. Vert. Paleont., 2, 33-49, 1982.

Arratia, G.: Basal teleosts and teleostean phylogeny, Palaeo Ichthyol., 7, 1-168, 1997.

Arratia, G.: The monophyly of Teleostei and stem group teleosts, in: Mesozoic Fishes - Systematics and Fossil Record, edited by: Arratia, G. and Schultze, H.-P., Verlag Dr. F. Pfeil, München, 265-334, 1999.

Arratia, G.: The varasichthyid and other crossognathiform fishes, and the break-up of Pangaea, in: Fishes and the Break-up of Pangaea, edited by: Cavin, L., Longbottom, A., and Richter, M., Geol. Soc., London, Spec. Publ. 295, 71-92, 2008a.

Arratia, G.: Actinopterygian postcranial skeleton with special reference to the diversity of fin ray elements, and the problem of identifying homologies, edited by: Arratia, G., Schultze, H.-P., and Wilson, M. V. H., Mesozoic Fishes 4 - Homology and Phylogeny, Dr. F. Pfeil, München, 49-101, 2008b.

Arratia, G.: Identifying patterns of the actinopterygian fulcra, Acta Zoologica, Stockholm, 90 (Suppl. 1), 220-235, 2009.

Arratia, G.: Los peces osteíctios fósiles de Chile y su importancia en los contextos paleobiogeográfico y evolutivo, in: Vertebrados Fósiles de Chile, edited by: Rubilar-Rogers, D., Otero, R., Vargas, A., and Sallaverry, M., Publicación Ocasional del Museo Nacional de Historia Natural No. 63, Santiago, Chile, 35-83, 2015.

Arratia, G. and Tischlinger, H.: The first record of Late Jurassic crossognathiform fishes from Europe and their phylogenetic importance for teleostean phylogeny, Foss. Rec., 13, 317-341, https://doi.org/10.1002/mmng.201000005, 2010.

Betancur, R. R., Wiley, E. O., Arratia, G., Acero, A., Bailly, N., Miya, M., Lecointre, G., and Orti, G.: Phylogenetic classification of bony fishes, BMC Evolutionary Biology, 42 pp., https://doi.org/10.1186/s12862-017-0958-3, 2017.
Blanco, A. and Cavin, L.: New Teleostei from the Agua Nueva Formation (Turonian), Vallecillo (NE México), C. R. Palevol., 2, 299-306, 2003.

Blanco-Piñón, A. and Alvarado-Ortega, J.: Fishes from La Mula Quarries, a new Late Cretaceous locality from the vicinity of Múzquiz, Coahuila, NE Mexico, in: Fourth International Meeting on Mesozoic Fishes: Systematics, Homology, and Nomenclature, Extended Abstracts, edited by: Poyato-Ariza, F. J., Madrid, Universidad Autónoma de Madrid, 37-41, 2005.

Bravo-Cuevas, V. M., González-Rodríguez, K. A., and EsquivelMacías, C.: Advances on the stratigraphy and paleontology of the Muhi Quarry from the mid-Cretaceous (Albian-Cenomanian) of Hidalgo, Central Mexico, Bol. Soc. Geol. Mex., 69, 155-165, 2009.

Bravo-Cuevas, V. M., González-Rodríguez, K. A., BañosRodríguez, R., and Hernández-Guerrero, C.: The Muhi Quarry: A fossil-lagerstätte from the mid-Cretaceous (AlbianCenomanian) of Hidalgo, Central México, in: Stratigraphic Analysis of Layered Deposits, edited by: Elitok, Ö., Rijeka, Croatia, 107-122, 2012 (in Czech).

Cavin, L.: Goulmimichthys arambourgi n. g., n. sp., un Pachyrhizodontidae (Actinopterygii, Teleostei) d'une nouvelle localité à nodules fossilifès du Turonien inférieur marocain, C. R. Acad. Sci., Paris t. 321 (ser. IIa), 1049-1054, 1995.

Cavin, L.: Osteology and phylogenetic relationships of the teleost Goulmimichthys arambourgi Cavin, 1995, from the Upper Cretaceous of Goulmima, Morocco, Birkhäuser Verlag, Basel, 509535, 2001.

Cope, E. D.: On the families of fishes of the Cretaceous formation in Kansas, Proc. Amer. Phil. Soc., Philadelphia, 12, 327-357, 1872.

Cumbaa, S. L. and Murray, A. M.: New Late Cretaceous pachyrhizodontoid fishes and associated ichthyofauna from the Northwest Territories, Canada, in: Mesozoic Fishes 4 - Homology and Phylogeny, edited by: Arratia, G., Schultze, H.-P., and Wilson, M. V. H., Verlag Dr. F. Pfeil, München, 229-256, 2008.

Dixon, F.: The geology and fossils of the Tertiary and Cretaceous Formations of Sussex, Richard and John Edward Taylor, London, 40, 374, 1850.

Espinosa-Arrubarrena, L. and Alvarado-Ortega, J.: Field trip to the Tlayúa Quarry, in: Fifth International Meeting on Mesozoic Fishes: Global Diversity and Evolution, Abstracts Book and Field Guides, Ciencia al Día, compiled by: González-Rodríguez, K. and Arratia, G., Universidad Autónoma del Estado de Hidalgo, Mexico, 19, 93-113, 2010.

Fielitz, C. and González-Rodríguez, K. A.: A new species of Ichthyotringa from El Doctor Formation (Cretaceous), Hidalgo, México, in: Mesozoic Fishes 4 - Systematics, Homology, and Nomenclature, edited by: Arratia, G., Schultze, H.-P., and Wilson, M. V. H., Verlag Dr. Friedrich Pfeil, München, 373-388, 2008.

Fielitz, C. and González-Rodríguez, K. A.: A new species of Enchodus (Aulopiformes: Enchodontidae) from the Cretaceous (Albian to Cenomanian) of Zimapán, Hidalgo, México, J. Vert. Paleontol., 30, 1343-1351, 2010.

Forey, P. L.: The osteology of Notelops Woodward, Rhacolepis Agassiz and Pachyrhizodus Dixon (Pisces: Teleostei), Bull. Brit. Mus. Nat. Hist. (Geol.), 28, 125-204, 1977.

Giersch, S., Frey, E., Ifrim, C., Stinnesbeck, W., and GonzálezGonzález, A. H., The ichthyofauna from the Upper Cretaceous 
locality Vallecillo (northeastern Mexico), in: Fifth International Meeting on Mesozoic Fishes: Global Diversity and Evolution, Abstracts Book and Field Guides: Ciencia al Día, compiled by: González-Rodríguez, K., and Arratia, G., Universidad Autónoma del Estado Hidalgo, Mexico, 19, 42, 2010a.

Giersch, S., Frey, E., Stinnesbeck, W., and González-González, A. H.: Pachyrhizodus caninus Cope, 1872 (Teleostei, Crossognathiformes) from the early Turonian of Vallecillo (Mexico), Neues Jahrb. Geol. Paläontol. Abh. Stuttgart, 258, 219-228, 2010 b.

González-Rodríguez, K. A. and Bravo-Cuevas, V. M.: Potencial fosilífero de la Cantera Muhi (Formación El Doctor: AlbianoCenomaniano) de la región de Zimapán, Estado de Hidalgo, Paleos Antiguo, 1, 27-42, 2005.

González-Rodríguez, K. A. and Fielitz, C.: A new species of acanthomorph fish from the Upper Cretaceous Muhi Quarry, Hidalgo, Central Mexico, in: Mesozoic Fishes 4 - Homology and Phylogeny, edited by: Arratia, G., Schultze, H.-P., and Wilson, M. V. H., Verlag Dr. F. Pfeil, München, 399-411, 2008.

González-Rodríguez, K. A., Espinosa-Arrubarrena, L., and González-Barba, G.: An overview of the Mexican fossil fish record, in: Mesozoic Fishes 5 - Global Diversity and Evolution, edited by: Arratia, G., Schultze, H.-P., and Wilson, M. V. H., Verlag Dr. F. Pfeil, München, 9-34, 2013a.

González-Rodríguez, K. A., Schultze, H.-P., and Arratia, G.: Miniature armored teleosts from the Albian-Cenomanian (Cretaceous) of Mexico, in: Mesozoic Fishes 5 - Global Diversity and Evolution, edited by: Arratia, G., Schultze, H.-P., and Wilson, M. V. H., Verlag Dr. Friedrich Pfeil, München, 457-487, 2013b.

González-Rodríguez, K. A., Fielitz, C., Bravo-Cuevas, V. M., and Baños-Rodríguez, R. E.: Cretaceous osteichthyan fish assemblages from Mexico, New Mexico Mus. Natur. Hist. Sci. Bull., 71, 107-119, 2016.

Günther, A. C. L. G.: Thrissopater salmoneus, in: Figures and descriptions of British organic remains, dec. xiii (I), Mem. Geol. Surv. Uk, London, I-4, 1872.

Hallam, A.: Early and mid-Jurassic molluscan biogeography and the establishment of the central Atlantic seaway, Palaeogeography, Palaeocl., 43, 181-193, 1983.

Heckel, J. J.: Beiträge zur Kenntnnis der fossilen Fische Österreichs, Denkschr. Akad. Wiss. Wien, 11, 187-274, 1856.

Hegna, T. A., Vega, F. J., and González-Rodríguez, K. A.: First Mesozoic Thylacocephalans (Arthropoda, ?Crustacea; Cretaceous) in the Western Hemisphere: New discoveries from the Muhi Quarry Lagerstätte, J. Paleont., 88, 606-616, 2014.

Jollie, M.: Chordate Morphology, Reinhold Publishing, New York, 478 pp., 1962.

Maisey, J. G.: Rhacolepis Agassiz, 1841, in: Santana Fossils; an illustrated atlas, edited by: Maisey, J. G., TFH Publications, Neptune, New Jersey, 248-257, 1991a.

Maisey, J. G.: Notelops Woodward, 1901, in: Santana Fossils; an illustrated atlas, edited by: Maisey, J. G., TFH Publications, Neptune, New Jersey, 258-271, 1991 b.

Müller, J.: Über den Bau und die Grenzen der Ganoiden und über das natürliche System der Fische, Bericht Akad. Wiss. Berlin, 1844, 416-422, 1845.

Nelson, J. S., Grande, T. C., and Wilson, M. V. H.: Fishes of the World, Wiley and Sons, Hoboken, New Jersey, 2016.
Páramo-Fonseca, M. E.: Los peces de la familia Pachyrhizodontidae (Teleostei) del Turoniano del Valle superior del Magdalena, Colombia, dos nuevas especies, Ingeominas, 39, 51-81, 2001.

Porter, S. J., Selby, D., Suzuki, K., and Gröcke, D.: Opening of a trans-Pangaean marine corridor during the Early Jurassic: Insights from osmium isotopes across the SinemurianPliensbachian GSSP, Robin Hood's Bay, UK, Palaeogeography, Palaeocl., 375, 50-58, 2013.

Schultze H.-P.: Nomenclature and homologization of cranial bones in actinopterygians, in: Mesozoic Fishes 4 - Homology and Phylogeny, edited by: Arratia, G., Schultze, H.-P., and Wilson, M. V. H., Verlag Dr. F. Pfeil, München, 23-48, 2008.

Schultze, H.-P. and González-Rodríguez, K. A.: Actinistian gular plates from the Cretaceous of Mexico and the problems assigning gular plates taxonomically, Foss. Rec., 19, 101-117, https://doi.org/10.5194/fr-19-101-2016, 2016.

Shimada, K.: Body form and paleoecology of the large Late Cretaceous bony fish, Pachyrhizodus caninus, Cretaceous Res., 52, 286-291, 2015.

Taverne, L.: Sur la position systématique et les affinités de Greenwoodella tockensis Taverne, L. et Ross, P. H. 1973 (Pisces Elopiformes) de l'Aptien inférieur de L'ile d'Helgoland (Allemagne), Bull. Inst. R. Sci. Nat. Belg. Sciences de la Terre, Aardwetenschappen, 49, 1-6, 1973.

Taverne, L.: Ostéologie et position systématique du genre Platinx (Pisces, Teleostei) de l'éocéne du Monte Bolca (Italie), Acad. Royale Belg., Bull. Classe Sciences, 5, 873-889, 1980.

Taverne, L.: Ostéologie et affinités du Téléostéen Crétacique Eloposis microdon (Pisces, Crossognathiformes, Pachyrhizodontidae), Biol. Jb. Dodonaea, 61, 172-192, 1994.

Taverne, L.: Crossognathus Pictet, 1858 du Crétacé inférieur de l'Europe et systématique, paleozoogéographie et biologie des Crossognathiformes nov. ord. (Téléostéens) du Crétacé et du Tertiaire, Palaeontographica, 207, 79-105, 1989.

Taverne, L.: Révision de Tingitanichthys heterodon (Arambourg, 1954) nov. gen. (Teleostei, Pachyrhizodontoidei) du Crétacé Supérieur marin du Maroc, Biol. Jb. Dodonaea, 63, 133-151, 1996.

Taverne, L.: Les poissons crétacés de Nardó. $29^{\circ}$. Nardopiscis cavini gen. et sp. nov. (Teleostei, Crossognathiformes, Pachyrhizodontidae), Boll. Mus. Civ. Stor. Nat. Verona. Geol. Paleont. Preist., 32, 19-28, 2008.

Toombs, H. A. and Rixon, A. E.: The use of plastics in the "transfer method" of preparing fossils, Museum Journal, London, 50, 105$107,1950$.

Voltani, C. G. and Bertini, R. J.: A respeito de ornamentações na estrutura maxilar de Rhacolepis buccalis Agassiz, 1841, in: Reunião Regional da Sociedade Brasileira de Paleontologia: PALEO SP-2012. APOIO, edited by: Almeida-Marsola, J. C. and Bronzati M., Universidade de São Paulo, Ribeirão Preto, São Paulo, Boletim de resumos, 48, 2012.

Wenz, S. and Fricot, C.: Présence de Pachyrhizodus salmoneus (Gûnther), Pisces, Teleostei, Pachyrhizodontidae, dans l' Albien moyen de l'Aube (France), Bull. d' information des geologues du bassin de Paris, 22, 7-10, 1985.

Woodward, A. S.: Catalogue of the fossil fishes in the British Museum (Natural History), Part IV, Trust. Brit. Mus (Nat. Hist.), 1901. 